\title{
ASSOCIATION OF POLYCYSTIC OVARY SYNDROME WITH INSULIN RESISTANCE AND GLUCOSE TRANSPORTER GLUT
}

1. MBBS, M.Phil

Senior Demonstrator Biochemistry

Allamah lqbal Medical College.

2. MSc, M.Phil, Ph.D

Assistant Professor Biochemistry

Shalamar Medical and Dental

College, Lahore.

3. MBBS, M.Phil

Associate Professor Biochemistry

Fatima Memorial Medical Collage,

Lahore.

4. MBBS, M.Phil

Senior Demonstrator Biochemistry Fatima Jinnah Medical University

Lahore.

5. MBBS

PGR Paeds

Mayo Hospital Lahore.

6. MBBS

PGR Endocrinology

Services Hospital Lahore.

Correspondence Address:

Dr. Uzma Jabbar

Department of Biochemistry

Shalamar Medical and Dental College Lahore.

uzmaimran5874@gmail.com

Article received on:

22/11/2019

Accepted for publication:

04/01/2020

\section{INTRODUCTION}

PCOS or polycystic ovary syndrome is a known impaired metabolic pathway disorder. It is caused by interplay between environmental and genetic factors. This may be characterized by insulin resistance in tissues of periphery, helps to increase the vulnerability of cardiovascular problems and type 2 diabetes. ${ }^{1}$

Additionally PCOS is linked with metabolic disturbances and mal functioning of hypothalamicpituitary-ovarian axis. The syndrome may results in increased levels of hormone androgen, insulin and its resistance. PCOS is also due to imbalance of ratio of $\mathrm{FSH}$ and $\mathrm{LH}$, infertility, endometrial dysfunction, obesity and increase risk of cardiovascular problems. ${ }^{2,3}$

Criteria of diagnosis of PCOS based upon age and increased BMI that may be linked with insulin resistance disturbances in metabolic pathways. The age related variations may effect on the incidence and complications of PCOS. ${ }^{4}$ A close link between obesity and PCOS may be age dependent and it may be related with reproductive and steroidogenic effects and insulin resistance. ${ }^{5}$ Increased values of BMI may be a factor of malfunctioning of excess amount of androgen and risk of miscarriages. ${ }^{6,7}$

About $70 \%$ of PCOS women have resistance of insulin related with altered function of glucose metabolism in adipose tissue. ${ }^{8}$ It is thought that insulin resistance secondary to diminished glucose uptake via insulin and increased secretion of insulin in PCOS may be a cause of decreased expression of GLUT4 (a glucose transporter). ${ }^{9}$

Additionally, it is proposed that increased expression of micro RNA 93 cause a down regulation of the expression of gene of GLUT in cells of adipose tissue. ${ }^{8}$ Role of micro RNA 93 in pathogenesis of PCOS revealed that over expression of non-coding RNA or micro RNA 
in ovarian tissue may be a reason of insulin resistance in PCOS women and also a reason of inhibition of synthesis of GLUT4. ${ }^{10}$ It is stated that uptake of blood glucose via insulin is directly dependent on availability of GLUT4. ${ }^{11}$

GLUT 4 or glucose transporter may take part in the progress of process of insulin resistance in both adipose and muscular tissues of PCOS women. ${ }^{12}$ It is measured that role of adipose tissue in uptake of glucose via insulin is only 10 $\%{ }^{13}$

Cross sectional study was designed to find out the association of PCOS with insulin resistance and glucose transporter GLUT 4.

\section{MATERIAL \& METHODS}

Study was included 37 PCOS women with age range 25-36 years were engaged from Gynae Department of Sir Ganga Ram Hospital Lahore. 20 age matched controls were medical staff of the hospital with no history of any disease. Duration of study was March 2016 to December 2016. Rotterdam's criteria were used to confirm PCOS. ${ }^{14}$ Women who have endocrinological disorder like hypo / hyper thyroidism, hyper prolectinemia, with cushing's syndrome and tumor of androgen were not included in the study.

Glucose oxidase method was used to estimate the level of fasting glucose. Level of circulating Insulin and GLUT4 was estimated by technique of ELISA using standard kits. Resistance of insulin and BMI was calculated by standard formula. ${ }^{15}$

Data was entered in SPSS 20. Variables were expressed as mean \pm SD. Variation in the values of BMI, levels of serum insulin, GLUT 4, fasting blood sugar and insulin resistance of patients was compared with the normal subjects using student ' $\mathrm{t}$ ' test. Values of $\mathrm{P}<0.05$ are considered significant.

\begin{tabular}{|c|c|c|}
\hline Study Variables & $\begin{array}{c}\text { PCOS women } \\
\text { (37) }\end{array}$ & $\begin{array}{l}\text { Normal } \\
\text { Subjects or } \\
\text { Controls (20) }\end{array}$ \\
\hline Age in years & $30.55 \pm 2.55$ & $29.00 \pm 2.22$ \\
\hline $\mathrm{BMI}\left(\mathrm{Kg} \mathrm{m}^{2}\right)$ & $29.77 \pm 4.39$ & $24.60 \pm 1.84$ \\
\hline $\begin{array}{l}\text { GLUT-4 } \\
\text { (arb. Units) }\end{array}$ & $4.77 \pm 4.08$ & $2.24 \pm 0.54$ \\
\hline $\begin{array}{l}\text { Blood glucose } \\
\text { fasting (mg/dl) }\end{array}$ & $\begin{array}{c}120.21 \pm \\
13.59 * *\end{array}$ & $95.0 \pm 9.5$ \\
\hline $\begin{array}{l}\text { Fasting serum } \\
\text { Insulin (IU/ml) }\end{array}$ & $32.54 \pm 14.13^{\star *}$ & $4.3 \pm 2.9$ \\
\hline $\begin{array}{l}\text { Glucose insulin } \\
\text { ratio }\end{array}$ & 4.52 & 29.45 \\
\hline $\begin{array}{l}\text { (Insulin } \\
\text { resistance) }\end{array}$ & $4.46 \pm 2.7^{\star *}$ & $0.44 \pm 0.6$ \\
\hline \multicolumn{3}{|c|}{$\begin{array}{l}\text { Table-I. Age, BMI and biochemical parameters in } \\
\text { PCOS women and their controls. } \\
\star * P<0.001 \text { showed significant difference }\end{array}$} \\
\hline
\end{tabular}

\section{RESULTS}

Mean age of PCOS patients and of controls was 30.55 and 29.00 years respectively. Values of BMI were insignificantly raised in PCOS compared to their controls.

Levels of GLUT-4 were insignificantly raised in PCOS women as in comparison to controls. On the other hand level of circulating fasting glucose and fasting insulin and insulin resistance were increased significantly $(P<0.001)$ in PCOS women in comparison to controls. Decreased glucose insulin ratio was observed in PCOS women in comparison to controls (Table-I).

\section{DISCUSSION}

Polycystic ovary syndrome is a known endocrinopathy observed in women during their reproductive period and also recognized to be a psychological and metabolic condition affecting 8 to $13 \%$ women, with a 4-5 fold amplified risk of type 2 diabetes and dyslipdemia. ${ }^{16}$

According to our study the mean age of PCOS patients and of controls was 30.55 and 29.00 years respectively. It is stated that there is variation in the phenotype of women having this disease throughout her life and may reorganize with aging. ${ }^{17}$ It is demonstrated insulin resistance along with obesity and metabolic disturbances 
are main problems in reproductive women with PCOS. ${ }^{4}$ Another study found that physiologic and metabolic dysfunctions of hypothalamic, ovarian, pituitary and adrenal may effect in the reproductive age of PCOS women. ${ }^{18}$

In our study values of BMI was insignificantly raised in PCOS in comparison to controls. According to another study, values of BMI were $27.47 \mathrm{Kg} / \mathrm{m}^{2}$ and found no significant relationship between occurrence of PCOS, age and BMI. ${ }^{19}$ It is proposed that insulin resistance along with steroidogenic and reproductive effects of increased level of serum insulin are the mediating effect of obesity. Production of adipokines via visceral and subcutaneous fat seems to play a role in metabolic function. ${ }^{5}$ A study stated that obesity exacerbates many signs of PCOS. It is thought obesity along with hirsuitism and infertility are major problem that may be a cause of stress in patients. ${ }^{20}$

Our results showed that levels of GLUT-4 were insignificantly raised in PCOS women in comparison to controls. Many study found that insulin mediated increased glucose uptake is directly depend on availability of GLUT4. ${ }^{11}$ A study observed that inhibition of synthesis of GLUT 4 via micro RNA is targeted by high mobility group A2 and also via sterol regulatory binding protein $1 .{ }^{10}$ Another study found that disturbance of the interaction between syntaxin binding protein and MUNC 18c protein in cells of adipose tissue may cause an increase externalization of insulin stimulated GLUT4. ${ }^{21}$ It is reported that this interaction of syntaxin binding protein and MUNC $18 \mathrm{c}$ protein mediate the process of exocytosis from beta cells of pancreas and also exocytosis of vesicles of GLUT4 from adipose tissue and skeletal muscle and increase insulin sensitivity. ${ }^{22}$

We observed a significant increased in the level of fasting blood glucose and serum insulin along with raised values of insulin resistance. Our study is agreed with no of studies. A study stated that increased level of insulin and luteinizing hormone may be related with risk of insulin resistance in most of the PCOS women. Study found than increase secretion of ovarian insulin may increase the granulose response of luteinizing hormone, which may increase the production of androgen. ${ }^{23}$ The worsening of insulin resistance during the life of reproductive women with PCOS seems to be a cause of obesity. ${ }^{4}$ A study experimentally proved that altered translocation of GLUT 4 to sarcolemma via stimulation of insulin may results insulin resistance. ${ }^{24}$

We found a decrease ration of glucose to insulin in our PCOS patients. According to a study the insulin sensitivity is related with ratio of blood glucose to serum insulin and a good predictive of insulin sensitivity index. Study found that fasting blood glucose serum insulin ratio $<7.0$ is considered as nonstandard and it is $<5.7$, it is a prove of insulin resistance. Study concluded that the ratio of fasting blood glucose to serum insulin is a good screening test for insulin resistance. ${ }^{25}$

\section{CONCLUSION}

A good association of polycystic ovary syndrome was observed with insulin mediated release of glucose transporter GLUT 4 and insulin resistance. However, further study is needed on large number of women with reproductive age to reach a better conclusion.

\section{Copyright $@ 04$ Jan, 2020.}

\section{REFERENCES}

1. Højlund K. Metabolism and insulin signaling in common metabolic disorders and inherited insulin resistance. Dan Med J. 2014 Jul; 61(7):B4890.

2. Sayyah-Melli M, Alizadeh M, Pourafkary $N$, et al. Psychosocial Factors Associated with Polycystic Ovary Syndrome: A Case Control Study. J Caring Sci. 2015; 4(3):225-31.

3. Li Y, Chen C, Ma Y, Xiao J, Luo G, Li Y, Wu D. Multi-system reproductive metabolic disorder: Significance for the pathogenesis and therapy of polycystic ovary syndrome (PCOS). Life Sci. 2019 Jul $1 ; 228: 167-175$.

4. Hsu MI. Changes in the PCOS phenotype with age. Steroids. 2013 Aug; 78(8):761-6. 
5. Barber TM, Hanson P, Weickert MO, Franks S. Obesity and polycystic ovary syndrome: Implications for pathogenesis and novel management strategies. Clin Med Insights Reprod Health. 2019 Sep 9; 13:11.

6. Metwally M, Ong KJ, Ledger WL, Li TC. Does high body mass index increase the risk of miscarriage after spontaneous and assisted conception? A metaanalysis of the evidence. Fertil Steril. 2008; 90:714726.

7. Yuan C, Liu X, Mao Y, Diao F, Cui Y, Liu J. Polycystic ovary syndrome patients with high BMI tend to have functional disorders of androgen excess: A prospective study. J Biomed Res. 2016; 30(3):197202.

8. Chen YH, Heneidi S, Lee JM, Layman LC, Stepp DW, Gamboa GM et al. microRNA-93 inhibits GLUT4 and is overexpressed in adipose tissue of polycystic ovary syndrome patients and women with insulin resistance. Diabetes. 2013 Jul; 62(7):2278-86.

9. Ezeh U, Chen IY, Chen YH, Azziz R. Adipocyte expression of glucose transporter 1 and 4 in PCOS: Relationship to insulin-mediated and non-insulinmediated whole-body glucose uptake. Clin Endocrinol (Oxf). 2019 Apr; 90(4):542-552.

10. Yang $Y$, Jiang $\mathbf{H}$, Xiao L, Yang X. MicroRNA-33b-5p is overexpressed and inhibits GLUT4 by targeting HMGA2 in polycystic ovarian syndrome: An in vivo and in vitro study. Oncol Rep. 2018 Jun; 39(6):30733085.

11. Olson AL. Regulation of GLUT4 and Insulin-Dependent Glucose Flux. ISRN Mol Biol. 2012; 2012:856987.

12. Rojas J, Chavez M, Oliver L, Rjos M, Morillo J, Mejias J et al. Polycystic Ovary Syndrome, Insulin Resistance, and Obesity: Navigating the pathophysiologic labyrinth. Int J of Repro Med 2014; 2014:17 pages.

13. Emanuel AL, Meijer RI, Mukiet MHA, van Raalte $\mathrm{DH}$, Eringa EC, Serne EH. Role of insulin-stimulated adipose tissue perfusion in the development of whole-body insulin resistance. Arteriosclerosis, Thrombosis, and Vascular Biology. 2017; 37:411-418.

14. Rotterdam ESHRE/ASRM-Sponsored PCOS Consensus Workshop Revised 2003 consensus on diagnostic criteria and long-term health risks related to polycystic ovary syndrome (PCOS). Hum Reprod. 2004; 19:41-47.

15. Macut D, Bjekić-Macut J, Rahelić D, Doknić M. Insulin and the polycystic ovary syndrome. Diabetes Res Clin Pract. 2017 Aug; 130:163-170.
16. Rodgers R, Avery J, Moore V, Davies M, Azziz R, StenerVictorin E et al. Complex diseases and co-morbidities: Polycystic ovary syndrome and type 2 diabetes mellitus. Endocr Connect. 2019 Mar; 8(3): R71-R75.

17. Lenart-Lipińska M, Beata Matyjaszek-Matuszek, Ewa Woźniakowska , Janusz Solski, Jerzy S. Tarach, Tomasz Paszkowski. Polycystic ovary syndrome: Clinical implication in perimenopause. Prz Menopauzalny $2014 ; 13(6)$ : 348-351.

18. Wolf WM, Wattick RA, Kinkade ON, Olfert MD. Geographical Prevalence of Polycystic Ovary Syndrome as Determined by Region and Race/ Ethnicity. Int J Environ Res Public Health. 2018; 15(11):2589.

19. Niksima SH, Odel NM, Khaki S, Ghanei Gheshlagh R, Fallahi A, Kurdi A. Prevalence of metabolic syndrome among Iranian women with polycystic ovary syndrome: A systematic review and metaanalysis. Diabetes Metab Syndr. 2019 May - Jun; 13(3):1911-1915.

20. Barthelmess EK, Naz RK. Polycystic ovary syndrome: Current status and future perspective. Front Biosci (Elite Ed). 2014; 6:104-19.

21. Aran V, Bryant NJ, Gould GW. Tyrosine phosphorylation of Munc18c on residue 521 abrogates binding to Syntaxin 4. BMC Biochemistry 2011; 12:1-19.

22. Ke B, Oh E, Thurmond DC. Doc2 $\beta$ Is a Novel Munc18cinteracting Partner and Positive Effector of Syntaxin 4-mediated Exocytosis. The Journal of Biological Chemistry 2007; 282: 21786-21797.

23. Wachs DS, Coffler MS, Malcom PJ, Shimasaki S, Chang RJ. Increased androgen response to folliclestimulating hormone administration in women with polycystic ovary syndrome. J Clin Endocrinol Metab. 2008; 93(5):1827-33.

24. Peng-Tao Xu, Zhen Song, Wen-Cheng Zhang, Bo Jiao, and Zhi-Bin Yu, "Impaired translocation of GLUT4 results in insulin resistance of atrophic soleus muscle. BioMed Research International, vol. 2015, Article ID 291987, 11 pages, 2015.

25. Vuguin $\mathbf{P}$, Saenger $\mathbf{P}$, Dimartino-Nardi J. Fasting glucose insulin ratio: A useful measure of insulin resistance in girls with premature adrenarche. $\mathbf{J}$ Clin Endocrinol Metab. 2001 Oct; 86(10):4618-21. 


\section{AUTHORSHIP AND CONTRIBUTION DECLARATION}

\begin{tabular}{|c|c|c|c|}
\hline Sr. \# & Author(s) Full Name & Contribution to the paper & Author(s) Signature \\
\hline 1 & Roohi Jabbar & $\begin{array}{l}\text { Study design, Data collection, } \\
\text { Writing the manuscript. }\end{array}$ & \\
\hline 2 & Rukhshan Khurshid & $\begin{array}{l}\text { Formulation of tables reviewed } \\
\text { and approved the manuscript. }\end{array}$ & on \\
\hline 3 & Uzma Jabbar & $\begin{array}{l}\text { Statistical analysis, } \\
\text { interpretation of resutls. }\end{array}$ & \\
\hline 4 & Mudassir Zia & $\begin{array}{l}\text { Formulation of tables reviewed } \\
\text { and approved the manuscript. }\end{array}$ & \\
\hline 5 & Abeera Mazhar Siddiqui & $\begin{array}{l}\text { Statistical analysis, interpretation } \\
\text { of resutls, Reviewed the } \\
\text { manuscript. }\end{array}$ & \\
\hline 6 & Farrukh Javaid & $\begin{array}{l}\text { Manuscript writing and revising it } \\
\text { critically for important intellectual } \\
\text { content. }\end{array}$ & \\
\hline
\end{tabular}

